\title{
Effects of size and apical or basal portions of the tiller on the morphology of elephant grass
}

\author{
Bruno Humberto Rezende Carvalho ${ }^{1}$, Bruno Nascimento Segatto, Kathleen \\ Alves Vasconcelos ${ }^{1}$, Gustavo Jordan da Silva Queiroz ${ }^{1}$, Jessica Abreu de Sa \\ Medica ${ }^{1}$, Manoel Eduardo Rozalino Santos ${ }^{1}$
}

\begin{abstract}
This work was developed to evaluate the effects of the size and the apical and basal portions of the tiller on the morphology of elephant grass (Pennisetum purpureum cv. Napier). Two experiments were performed. In the first one, the characteristics were evaluated of basal tiller with four sizes $(80,120,160$ and $200 \mathrm{~cm})$. A completely randomized design was used, with three replications. In the second experiment, the morphology of the basal and apical portions, from small tillers $(100 \mathrm{~cm})$ and large $(180 \mathrm{~cm})$ elephant grass were evaluated. The design was completely randomized and the split-plot scheme was used, with three replications. The numbers of living and dead leaves, stem and leaf lengths, leaf blade width, and tiller mass increased linearly with elephant grass size. The basal portion of the elephant grass tiller had a higher mass (56.2 g), higher percentages of leaf dead (2.1\%) and live stem (89.5\%), and a lower percentage of live leaf blade (23.4\%) than the apical portion. With the increase in size, the elephant grass tiller presents a higher percentage of structural tissues and with a higher stage of development, as well as a lower percentage of photosynthetic tissues. The apical portion of the elephant grass tiller has a higher percentage of photosynthetic tissues and a lower percentage of structural tissues and a higher stage of development compared to the basal portion of the tiller.
\end{abstract}

Keywords: Stem, Leaf, Pennisetum purpureum, Senescence.

\section{RESUMO}

Este trabalho foi desenvolvido para avaliar os efeitos do tamanho e das porções apical e basal do perfilho sobre a morfologia do capim-elefante (Pennisetum purpureum cv. Napier). Dois experimentos foram realizados. No primeiro, foram avaliadas as características dos perfilhos basilares com quatro tamanhos $(80,120,160$ e $200 \mathrm{~cm})$. Adotou-se o delineamento inteiramente casualizado, com três repetições. No segundo experimento, foi avaliada a morfologia das porções basal e apical, oriundas de perfilhos pequeno $(100 \mathrm{~cm})$ e grande $(180 \mathrm{~cm})$ do capim-elefante. Adotou-se o delineamento inteiramente casualizado e o esquema de parcela subdividida, com três repetições. Os números de folhas vivas e mortas, os

\footnotetext{
${ }^{1}$ Faculdade de Medicina Veterinária e Zootecnia da Universidade Federal de Uberlândia *corresponding author: Rua Ceará s/n, Bloco 2D, Bairro Umuarama, Uberlândia, MG 38402-018, Brazil. Email: manoel.rozalino@ufu.br
} 
comprimentos do colmo e da lâmina foliar, a largura da lâmina foliar, e a massa do perfilho aumentaram linearmente com o tamanho do perfilho de capim-elefante. A porção basal do perfilho de capim-elefante possuiu maior massa $(56,2 \mathrm{~g})$, superiores percentagens de lâmina foliar morta $(2,1 \%)$ e de colmo vivo $(89,5 \%)$, e menor percentagem de lâmina foliar viva $(23,4 \%)$ do que a porção apical. Com o incremento do tamanho, o perfilho de capimelefante apresenta maior percentagem de tecidos estruturais e com maior estádio de desenvolvimento, bem como inferior percentagem de tecidos fotossintéticos. A porção apical do perfilho de capim-elefante possui superior percentagem de tecidos fotossintéticos e menor percentagem de tecidos estruturais e com maior estádio de desenvolvimento, em comparação à porção basal do perfilho.

Palavras-chave: Colmo, Folha, Pennisetum Purpureum, Senescência.

\section{Introduction}

A grass is composed of several aggregate tillers, which are their basic units of development. One way to identify the development stage of individual tillers is to evaluate their size, expressed as length, since longer tillers usually have a greater number of phytomers and these are more developed. In this sense, tillers characterization by size allows inferences to be made on pasture, which is fundamental to explain the responses of forage plants and grazing animals (Carvalho et al., 2005).

The fact that the tillers are formed by phytomers, one above the other and with different development stages, causes that in the vertical profile of the same tiller there is a variation of their morphological characteristics, which will also result in morphological variability in the vertical pasture profile. Thus, the organs located at the most basal extract of the tiller have a higher stage of development, contrary to the findings in the upper extracts. This makes the morphology of the basal and apical part of the tiller different, which has implications for grazing animal consumption (SANTOS et al., 2010a).

Indeed, when ruminants consume the basal strata of pasture, there is a tendency for them to express lower consumption and hence lower performance. On the other hand, when ruminants consume upper pasture 
extracts, higher animal performance tends to be obtained (DIFANTE et al., 2009).

Considering the above, it is relevant to understand the morphological changes that occur between tiller types and between parts of the same tiller, in order to better understand the sward structure, that is, the distribution and arrangement of organs of the aerial part of the forage plants, that influence the responses of plants and animals in grazing (SANTOS et al., 2010a).

In fact, many forage studies have focused on the smaller evaluation scales of forage plants, such as the individual tillers, which are the developmental units of grasses (SBRISSIA AND DA SILVA, 2008; GARCEZ NETO et al. (1990). These reductionist studies help to understand better the responses of forage plants to different environmental conditions, including man-made management. Thus, this work was developed to evaluate the effects of the size and the apical and basal portions of the tiller on the morphology of the elephant grass (Pennisetum purpureum cv. Napier).

\section{Material and methods}

This work was conducted in an area of Pennisetum purpureum cv. Cameroon (elephant grass), established in 2005 and traditionally used as capineira, belonging to the Animal Science School of the Federal University of the São Francisco Valley, in Petrolina-PE. The approximate geographical coordinates of the experiment site are $09^{\circ} 23^{\prime}$ 'south latitude and $40^{\circ} 30^{\prime}$ west longitude and the altitude is $376 \mathrm{~m}$.

The climate of Petrolina is of type BshW, tropical semi-arid, characterized by scarcity and irregularity of the precipitations, with rains in the summer and with strong evaporation as a consequence of the high temperatures. Regarding the air temperature, the monthly normals present average variations of $24.2^{\circ} \mathrm{C}$ to $28.2^{\circ} \mathrm{C}$, being July the coldest month and 
November, the hottest of the year. In the last 30 years, the average annual total was 567 mm (LEÃO E SOARES, 2000).

The soil of the experimental area has a Yellow Latosol of sandy texture. The chemical analysis of the soil, performed in the $0-20 \mathrm{~cm}$ layer, presented the following results: $\mathrm{pH}$ in H2O: 6.7; P: $15.93 \mathrm{mg} / \mathrm{dm} 3$ (Mehlich1); K+: 0.59; Ca2+: 3.4; Mg2+: 0.8 and Al3+: 0.0 cmolc/dm3 ( $\mathrm{KCl} 1 \mathrm{~mol} / \mathrm{L})$. The fertilization was carried out in every experimental area in January and March, with two applications of $75 \mathrm{~kg} / \mathrm{ha}$ of $\mathrm{N}$ and $\mathrm{K} 2 \mathrm{O}$, as well as $25 \mathrm{~kg} / \mathrm{ha}$ of P2O5, using the formulated 20-05-20.

In the same experimental area, two research works on the morphology of elephant grass tiller were conducted independently. To accomplish that, in April 2010, three areas (experimental units) were selected, each one with approximately $4 \mathrm{~m} 2$, for sampling tillers. In these areas, elephant grass was about $1.80 \mathrm{~m}$ tall on average.

In the first study, the characteristics of basal tiller were evaluated with four different sizes, namely: 80, 120, 160 and $200 \mathrm{~cm}$ in length. A completely randomized design was used, with three replications. The evaluation of tillers with varying sizes in the same pasture area was possible due to the diversity of tiller sizes existing in the same grass plant (SANTOS et al., 2011).

In each experimental unit, four samples were collected, each of ten tillers with different sizes evaluated (80, 120, 160 and $200 \mathrm{~cm}$ ). The tillers had their younger leaves extended to measure their size and were cut to the level of the soil surface, identified and taken to the laboratory. In each sample, the numbers of living and dead leaves of the tiller were quantified. Dead leaf was considered to be one with more than $50 \%$ of its senescent length. Also measured were the length and width of the leaf blades of the median portion of the tillers, as well as the length of the stem. The width corresponded to the distance between the edges of the leaf blade, measured in its central region; the length consisted of the distance between the ligula 
and the apex of the leaf blade; while the length of the stem was measured as the distance from the base of the tiller to the ligule of the youngest fully expanded leaf.

Subsequently, from each sample, the living leaf blade, live stem and dead leaf blade were manually separated. Separately, these morphological components were placed in paper bags and taken to the forced ventilation oven at $65^{\circ} \mathrm{C}$, remaining in it for 72 hours. After that, these morphological components were weighed. With these data, the tiller mass, the percentages of living leaf, live stem and dead leaf blade, as well as the relationship between living leaf mass and live stem mass were calculated.

The second experiment was carried out in April 2010, where three areas (experimental units) were selected from the same pasture as described in the first experiment, each with approximately $4 \mathrm{~m} 2$, for evaluating the morphology of the basal and apical portions, from small and large tillers of elephant grass. The largest tillers were with $1.80 \mathrm{~m}$ long; and the small tiller corresponded to the one with $1.0 \mathrm{~m}$ length. The design was completely randomized and the split-plot scheme was used, with three replications. The tiller size factor corresponded to the plot, while the tiller portion was the subplot.

In each experimental unit, two samples were collected, one consisting of small tillers and the other of large tillers. In each sample, 10 basal tillers were harvested at the vegetative growth stage. The tillers were cut at the level of the soil surface, identified and taken to the laboratory. Firstly, in each sample, all the tillers were sectioned in two parts of equal length, in order to obtain two subsamples, each corresponding to the evaluated portions (basal and apical). Subsequently, from each sub-sample, the morphological components (living leaf, live stem, and dead leaf blade) were manually separated, oven dried and weighed, following the same procedures used during the conduction of the first experiment. With these data, the 
tiller mass was calculated, as well as its percentages of living leaf blade, living stem and dead leaf blade.

Analyzes of the experimental data were done separately for each study. In the first study, for each characteristic, analyzes of variance and regression were performed according to the size of the tiller, whose model that best fit the data was linear. The degree of adjustment of the models was evaluated by the coefficient of determination and the significance of the regression coefficients, tested by the t-test corrected based on the residues of the analysis of variance. In the second study, analyzes of variance were performed to compare tiller types (small or large), tiller portions (apical or basal), as well as their possible interactions, by the $\mathrm{F}$ test. In all analyzes, $5 \%$ was adopted as a critical level of probability for type I error.

\section{Results and discussion}

All the organs evaluated had their dimensions and, or, their numbers increased linearly with the size of the elephant grass tiller (Table 1).

The living leaf number increased $(\mathrm{P}<0.05)$ with the size of the tiller (Table 1). When in free growth and at a more advanced stage of development, elephant grass reaches a great natural height, above $3.5 \mathrm{~m}$ in some conditions. Thus, it is possible that the tiller size levels evaluated in this study included younger tillers of this plant. In this situation, probably, the tillers had not yet reached their maximum number of living leaves, which would explain the increase in this variable with the tiller size.

Regarding the number of dead leaf, its increase $(\mathrm{P}<0.05)$ with the till size probably occurred due to the more pronounced shading of the basal leaves of the more developed and larger tillers. In this condition, the leaf is in an environment with a solar radiation level lower than its light compensating point, which results in its negative carbon balance, characterized by a higher rate of respiration in relation to that of 
photosynthesis and, as a consequence, the leaf senesce (TAIZ AND ZEIGER, 2006). In addition, the basal leaves of longer tillers are also of greater age and may have exceeded their life-span, which also contributes to the increase of dead leaf number in tillers with larger sizes (Table 1).

Table 1. Structural characteristics as a function of size (S) of elephant grass tillers.

\begin{tabular}{lllllll}
\hline \multirow{2}{*}{ Variable } & \multicolumn{2}{l}{ Size $(\mathrm{cm})$} & \multirow{2}{*}{ Regression equation } & $\mathrm{R}^{2}$ \\
\cline { 2 - 5 } & 80 & 120 & 160 & 200 & & 0.92 \\
\hline LLN & 8.9 & 9.3 & 11.1 & 13.7 & $\hat{\mathrm{Y}}=5.145+0.0401 * \mathrm{~S}$ & 0.69 \\
DLN & 0.1 & 0.6 & 0.3 & 1.9 & $\hat{\mathrm{Y}}=-1.1217+0.0133 * \mathrm{~S}$ & 0.98 \\
SL & 19.8 & 42.3 & 88.5 & 123.7 & $\hat{\mathrm{Y}}=-56.676+0.8945 * \mathrm{~S}$ & 0.99 \\
LBL & 49.4 & 68.4 & 80.1 & 98.3 & $\hat{\mathrm{Y}}=18.61+0.396 * \mathrm{~S}$ & 0.93 \\
LBW & 1.8 & 2.0 & 2.6 & 3.6 & $\hat{\mathrm{Y}}=0.375+0.015 * \mathrm{~S}$ & \\
\hline
\end{tabular}

LLN: living leaf number; DLN: dead leaf number; SL: stem length; LBL leaf blade length; LBW: leaf blade width.

* Significant by test $\mathrm{t}(\mathrm{P}<0.05)$.

It is worth mentioning that only the larger size tiller $(200 \mathrm{~cm})$ presented more than one dead leaf (Table 1). It indicates that, in general, the tillers evaluated in this work were at a lower stage of development, as discussed previously.

The stem length was elevated $(\mathrm{P}<0.05)$ with the largest size of the elephant grass tiller (Table 1). This is due to the greater number of phytomers in larger tillers. As each phytomer is constituted, among other organs, of internode, it becomes natural the greater length of the stem in longer tiller. In addition, a greater number of living leaves in larger tillers (Table 1) also requires a more developed stem to sustain them.

Regarding the dimensions of the leaf blade, its length and width increased $(\mathrm{P}<0.05)$ with the tiller size (Table 1$)$. In vegetative shoots of larger size, younger leaves have to travel a greater distance between the point of connection with the meristem and the end of the pseudostem, which results in their longer length compared to the leaves of smaller tillers (SKINNER AND NELSON, 1995). And the longest leaf length of elephant grass is associated with its greater width. 
The structural characteristics are determinant of the mass and the morphological composition of elephant grass tillers. In this context, the increase in leaf numbers and the size of leaves and stems in larger tillers (Table 1) justify the larger mass $(\mathrm{P}<0.05)$ of these tillers (Table 2$)$.

Table 2. Mass and morphological composition as a function of size (S) of elephant grass tiller.

\begin{tabular}{lllllll}
\hline \multirow{2}{*}{ Variable } & \multicolumn{2}{l}{ Size $(\mathrm{cm})$} & \multirow{2}{*}{ Regression } & $\mathrm{R}^{2}$ \\
\cline { 2 - 5 } & 80 & 120 & 160 & 200 & & 0.88 \\
\hline Mass (g) & 23.8 & 44.9 & 153.9 & 363.6 & $\hat{\mathrm{Y}}=-248.34+2.8206 * \mathrm{~S}$ & 0.94 \\
LLB (\%) & 64.8 & 61.0 & 45.2 & 40.4 & $\hat{\mathrm{Y}}=84.045-0.2228 * \mathrm{~S}$ & 0.74 \\
DLB (\%) & 0.2 & 0.7 & 0.5 & 2.0 & $\hat{\mathrm{Y}}=-0.9358+0.0128 * \mathrm{~S}$ & 0.92 \\
LS (\%) & 35.0 & 38.3 & 54.2 & 57.7 & $\hat{\mathrm{Y}}=16.891+0.2100 * \mathrm{~S}$ & 0.93 \\
LLB/LS & 1.9 & 1.6 & 0.8 & 0.7 & $\hat{\mathrm{Y}}=2.7373-0.0106 * \mathrm{~S}$ & 0.9 \\
\hline
\end{tabular}

LB live leaf blade; DLF: dead leaf blade; LS Live stem; LLB/LS: relationship between the masses of LLB and LS;

* Significant by the $t$ test $(\mathrm{P}<0.05)$.

The positive effect of tiller size on the length of its stem (Table 1) is also the reason for the linear increase $(\mathrm{P}<0.05)$ of the percentage of live stem with the tiller size (Table 2). Similarly, the linear increase of dead leaf blade participation $(\mathrm{P}<0.05)$ with tiller size (Table 2$)$ was due to the positive effect of tiller size on dead leaf number (Table 1). On the other hand, the increase in stem length in larger tillers, which can be perceived by the high coefficient of their regression equation, it has been much more pronounced than the increases in leaf number and dimension (Table 1). This caused the percentage of living leaf to decrease linearly $(\mathrm{P}<0.01)$ with the tiller size, in the same way as the relationship between masses of the living leaf and the living stem (Table 2).

Based on the morphological changes that occurred with the increase in the tiller size, it is possible to infer that the larger tillers have a worse nutritive value, since they are composed of higher percentage of stem and dead leaf, morphological components of worse nutritive value in relation to the leaf blade (SANTOS et al., 2010b). As a consequence, it can also be deduced that pastures under large rest periods, in which larger tillers are 
common, they are also not suitable for the ruminant consumption and performance. Thus, management actions that control the tiller size in a pasture have a positive effect on animal productivity. This can be one of the reasons why grazing management, based on pasture height control, has been shown to be effective in pasture management (DA SILVA and NASCIMENTO JR, 2007). With the control of the sward height the tiller height is also controlled, making them have a more favorable morphology, concomitantly, to the plant growth and the animal consumption.

Regarding the basal and apical portions of the small and large elephant grass tillers, no interactions were observed among the studied factors (Table 3). It has been verified that the basal portion had $(\mathrm{P}<0.05)$ greater mass, higher percentages of dead leaf blade (DLB) and of live stem (LS), but a lower percentage of leaf blade alive (LLB), compared to the apical portion of the tiller (Table 3).

Table 3. Mass and morphological composition of the apical and basal parts in elephant grass tillers with large or small size.

\begin{tabular}{llll}
\hline & \multicolumn{2}{l}{ Part of the tiller } & \multirow{2}{*}{ Average } \\
\cline { 2 - 3 } Tiller sizer & Basal & Apical & \\
\hline & Mass (g) & & $63.34 \mathrm{a}$ \\
Big & 92.00 & 34.67 & $14.83 \mathrm{~b}$ \\
Small & 20.33 & 9.33 & \\
Average & $56.17 \mathrm{~A}$ & $22.0 \mathrm{~B}$ & \\
& Living leaf blade (\%) & & $49.72 \mathrm{~b}$ \\
Big & 7.99 & 91.45 & $69.41 \mathrm{a}$ \\
Small & 38.82 & 100.00 & \\
Average & $23.41 \mathrm{~B}$ & $95.73 \mathrm{~A}$ & \\
& Dead leaf blade (\%) & & $1.26 \mathrm{a}$ \\
Big & 2.51 & 0.00 & $0.82 \mathrm{~b}$ \\
Small & 1.63 & 0.00 & \\
Average & $2.07 \mathrm{~A}$ & $0.00 \mathrm{~B}$ & \\
& Live stem (\%) & & $49.03 \mathrm{a}$ \\
Big & 89.50 & 8.55 & $29.78 \mathrm{~b}$ \\
Small & 59.55 & 0.00 & \\
Average & $74.53 \mathrm{~A}$ & $4.28 \mathrm{~B}$ & \\
\hline
\end{tabular}

Means followed by the same capital letter in the row and lowercase in the column do not differ by the $\mathrm{F}$ test $(\mathrm{P}<0.05)$. 
These results can be explained by the existence of morphological variability along the vertical profile of the tiller, which is due to the presence of phytomers with different development stages in the same tiller (SANTOS et al., 2010a). In this sense, at the basal part of the tiller, the phytomers are formed first, that is, they are older; whereas, in the apical part, there are phytomers newly formed and, therefore, being younger. This is a determinant of the highest $(\mathrm{P}<0.05)$ percentages of DLB and LS and the lowest $(\mathrm{P}<0.05)$ percentage of LLB at the basal part of the tiller, when compared to the apical part (Table 3).

In comparison to the apical part, at the basal part of the tillers, the older leaves are present, which normally reached their limit of life-span. Consequently, they have already or are in course of finishing their senescence process. In addition, at the basal part of the tiller, they also find those leaves that normally receive lower level of solar radiation, which also contributes to increasing their senescence (LEMAIRE, 2001). These factors explain the higher percentage of DLB and the lower percentage of LLB at the basal part of the tiller (Table 3).

Based on the results in Table 3 , it can be deduced that the apical part of the tillers presents better nutritional value than the basal part. It would explain, in part, the fact that ruminants preferentially consume the organs located in this first part of the tiller. Additionally, these results also explain that when the animal is forced to consume the basal part of the pasture, it has a limited performance (DIFANTE et al., 2009). This is attributable to the basal portion of the tiller and, in fact, of the pasture has a greater amount of dead tissues, which present worse nutritional value (SANTOS et al., 2010b).

Moreover, at the basal portion of the tiller, there is also a greater amount of structural tissues (stem), which are more difficult to grasp by the animal during grazing, due to the greater shear force of the stem (NAVE et al., 2010). This fact also limits the consumption and performance of 
ruminants when managing the pasture with a sizeable removal of its vertical profile, that is, with low post-grazing residue.

Regarding the size of the tiller, it was verified that the large tiller (1.80 $\mathrm{m}$ in length) had higher values $(\mathrm{P}<0.05)$ of mass and percentages of DLB and LS, when compared to the small tiller (1.0 m long) (Table 3). These results presented the same pattern of response as those obtained with the first experiment (Tables 1 and 2).

\section{Conclusions}

With increasing size, the Pennisetum purpureum tiller exhibits a higher relative participation of structural tissues and with a higher stage of development, as well as a lower percentage of photosynthetic tissues.

The apical portion of the Pennisetum purpureum tiller has a higher percentage of photosynthetic tissues and a lower relative participation of structural tissues and with a higher developmental stage compared to the basal portion of the tiller.

\section{Acknowledgments}

Thanks to the Animal Science School of the Federal University of the São Francisco Valley (Colegiado de Zootecnia da Universidade Federal do Vale do São Francisco UNIVASF) for the concession of the infrastructure to carry out the research.

\section{References}

CARVALHO, P.C.F. O manejo da pastagem como gerador de ambientes pastoris adequados à produção animal. In: MOURA, J.C.; DA SILVA, S. C; DE FARIA, V.P. (Eds.) SIMPÓSIO SOBRE MANEJO DA PASTAGEM, 22.2005, Piracicaba. Anais... Piracicaba: FEALQ, 2005. p.07-31. 
DA SILVA, S.C.; NASCIMENTO JÚNIOR, D. Avanços na pesquisa com plantas forrageiras tropicais em pastagens: características morfofisiológicas e manejo do pastejo. Revista Brasileira de Zootecnia, v.36, n.4, p.121-138, 2007 (suplemento especial).

DIFANTE, G.S; EUCLIDES, V.P.B.; NASCIMENTO JÚNIOR, D. et al. Ingestive behaviour, herbage intake and grazing efficiency of beef cattle steers on Tanzania guineagrass subjected to rotational stocking managements. Revista Brasileira de Zootecnia, v.38, n.6, p.1001-1008, 2009.

GARCEZ NETO, A.M.; GOBBI, K.F.; SILVA, J.; SANTOS, T.M. Tillering and biomass partitioning of Mombasa grass under nitrogen fertilization during regrowth. Revista Brasileira de Zootecnia, v.41, n.8, p.1824-1831, 2012.

HODGSON, J. Grazing management - science into practice. Essex: Longman Scientific \& Technical, 1990, p.203.

LEÃO, P.C.S., SOARES, J.M. A Viticultura no semi-árido brasileiro. Petrolina: Embrapa Semi-Árido, 2000, p. 15-16.

LEMAIRE, G. Ecophysiology of grasslands: dynamic aspects of forage plant. Populations in grazed swards. In: INTERNATIONAL GRASSLAND CONGRESS, 2., Piracicaba, 2001. Proceedings... Piracicaba: FEALQ, 2001. CD-ROM.

NAVE, R.L.G.; PEDREIRA, C.G.S.; PEDREIRA, B.C. Nutritive value and physical characteristics of Xaraes palisadegrass as affected by grazing strategy. South African Journal of Animal Science, v.40, n.4, p.285-293, 2010.

SANTOS, M.E.R.; AQUINO, R.F.S.F.; ROMÃO, M.C. et al. Morfologia das porções apical e basal de perfilhos de capim-braquiária. Enciclopédia Biosfera, v.6, n.11, p.1-7. 2010 a. 
SANTOS, M.E.R.; FONSECA, D.M.; BALBINO, E.M. et al. Valor nutritivo de perfilhos e componentes morfológicos em pastos de capim-braquiária diferidos e adubados com nitrogênio. Revista Brasileira de Zootecnia, v.39, n.9, p.19191927. 2010 b.

SANTOS, M.E.R.; FONSECA, D.M.; GOMES, V.M. et al. Diversidade de perfilhos em pasto de Brachiaria decumbens manejado em regime de lotação contínua. Boletim de Indústria Animal, v.68, n.1, p.17-26. 2011.

SBRISSIA, A. F.; DA SILVA, S. C. Compensação tamanho/densidade populacional de perfilhos em pastos de capim-marandu. Revista Brasileira de Zootecnia, v. 37, n. 1, p. 35-47, 2008.

SOUZA, B.M.L.; VILELA, H.H.; SANTOS, M.E.R. et al. Characterization of tillers in deferred Piata palisade grass with different initial heights and nitrogen levels. Revista Brasileira de Zootecnia, v.41, n.7, p.1618-1624, 2012.

SKINNER, R.H.; NELSON, C.J. Elongation of the grass leaf and its relationship phillochron. Crop Science, v.35, n.1, p.4-10, 1995.

TAIZ, L.; ZEIGER, E. Fisiologia Vegetal. Porto Alegre: Artmed, 3 ed., 2006. 719p. 